\title{
Drought-Induced Changes in Wood Density Are Not Prevented by Thinning in Scots Pine Stands
}

\author{
David Candel-Pérez ${ }^{1}$, Yueh-Hsin Lo ${ }^{1}$, Juan A. Blanco ${ }^{1, *}$ (D), Chih-Ming Chiu ${ }^{2}$, \\ J. Julio Camarero ${ }^{3}{ }^{(1 D}$, Ester González de Andrés ${ }^{1}$, J. Bosco Imbert ${ }^{1}$ and Federico J. Castillo ${ }^{1}$ \\ 1 Department of Ciencias del Medio Natural, Universidad Pública de Navarra, Pamplona 31006, Spain; \\ david.candel@unavarra.es (D.C.-P.); yuehhsin.lo@gmail.com (Y.-H.L.); \\ ester.gonzalez@unavarra.es (E.G.d.A.); bosco.imbert@unavarra.es (J.B.I.); \\ federico.castillo@unavarra.es (F.J.C.) \\ 2 Division of Forest Management, Taiwan Forestry Research Institute, Taipei 10066, Taiwan; \\ cmchiu@tfri.gov.tw \\ 3 Instituto Pirenaico de Ecología, Zaragoza 50166, Spain; jjcamarero@ipe.csic.es \\ * Correspondence: juan.blanco@unavarra.es; Tel.: +34-948-169-859
}

Received: 12 October 2017; Accepted: 6 December 2017; Published: 2 January 2018

\begin{abstract}
Density is an important wood mechanical property and an indicator of xylem architecture and hydraulic conductivity. It can be influenced by forest management and climate. We studied the impact of thinning and climate variables on annual stem radial growth (ring width and ring density, and their earlywood and latewood components) in two contrasting Scots pine (Pinus sylvestris L.) stands in northern Spain (one continental, one Mediterranean). At each site, three thinning regimes (control or $\mathrm{T} 0$, removing $20 \%$ basal area or $\mathrm{T} 20$, and removing $30 \%$ or $\mathrm{T} 30$ ) were randomly applied to nine plots per site (three plots per treatment) in 1999. Thinning was repeated at the Mediterranean site in 2009 (increasing thinning intensity in T30 to 40\%). Eight trees per plot were cored in spring 2014. Second thinning at the Mediterranean site and first thinning at the continental site generally caused significantly wider ring (RW), earlywood (EW) and latewood (LW) widths, although no differences between T20 and T30/40 were found, supporting in part the common observation that radial growth is enhanced following thinning as competition for water and nutrients is reduced. At the Mediterranean site, values of latewood density (LD) and maximum density (Dmax) relative to pre-thinning conditions were significantly lower in T0 than in T30. However, at the continental site, relative changes of ring density (RD) and LD were significantly higher in T0 than in T20 and T30. Climate significantly affected not only RW but also RD, with significant RD drops during or right after unusually warm-dry years (e.g., 2003, 2011), which were characterized by LD reductions between 5.4 and $8.0 \%$. Such RD decreases were quickly followed by recovery of pre-drought density values. These results indicate trees temporarily reduce $\mathrm{LD}$ as a way to enhance hydraulic conductivity during dry summers. However, climate effects on wood density were site-dependent. We also detected that the thinning effect was not intense enough to prevent drought-induced changes in wood density by altering water availability, but it could help to reduce wood properties fluctuations and therefore maintain more homogeneous wood mechanic features.
\end{abstract}

Keywords: dendroecology; Scots pine; tree-ring width; wood density; X-ray densitometry; drought

\section{Introduction}

Annual tree rings record interactions between trees and environment [1]. In conifers, the anatomical changes of tracheids through the growing season are characterized by the formation of narrower lumen areas, thicker walls and more dense wood along the gradual transition from earlywood to latewood [2]. Variation in wood characteristics (e.g., tracheid lumen area, wood density, or latewood percentage) 
within and between trees is affected by a number of factors including stand structure, tree age, environmental conditions and genetics [3,4].

Physiological drivers of wood-density changes between and within tree rings are related to cambial activity and depend on factors modulating the activity of this meristem, including tree size and age, and seasonality in climate conditions [5]. Moreover, wood density is sensitive to environmental changes, such as water availability, drought stress and temperature fluctuations [6,7]. However, the relationships between stand attributes, tree growth rate and wood density in conifers are unclear [8].

Tree radial growth within forest stands mainly depends on the interactions between tree-to-tree competition and environmental conditions [9]. Some of these stand factors, such as density, can be manipulated by forest managers to achieve desired wood quality outcomes [10]. The effects of silviculture on wood properties, particularly timber density, are often assumed to be a consequence of their impacts on radial-growth rates. Wood density is also a reliable indicator of stem's hydraulic properties, as it is related to both growth rate and hydraulic efficiency. A better understanding of the relationships between wood density and growth rates is relevant to comprehend the role played by forests in carbon sequestration and biomass production [11]. Wood density has long been considered the most important wood quality attribute, and a high-density wood is usually associated with high lumber strength and stiffness [12]. In general, wood density is negatively influenced by the tree growth rate in softwoods.

Tree growth and wood density can be directly managed by different silvicultural treatments to manipulate stand conditions [13]. When properly used, thinning reduces long-term competition stress, and may increase resilience and resistance of trees to extreme drought events [14-16]. On the other hand, radial growth responses to climate vary considerably according to stand tree density in water-limited areas such as the Mediterranean basin [17]. A reduction of growth sensitivity to water shortage usually results from thinning practices in drought-prone areas [18].

Forest management may therefore affect wood properties and tree growth performance through the intensity and type of thinning, changing tree species composition, altering trees' competitive status and affecting whether juvenile or mature wood is being formed [19]. Thinning interventions also positively affect the amount of incident light, available nutrients [20] and temperatures inside the stand [21]. All these factors can potentially impact tracheid growth and development, and in turn affect wood density. In fact, the effects of silvicultural management on wood properties have been studied over decades in productive tree species such as Scots pine (Pinus sylvestris L.) [22]. However, information on the effects of thinning on individual ring density and ring growth is meager and fragmentary [23], and often shows conflicting results [19,24].

Thinning usually decreases competition among the remaining trees by improving the availability of water and nutrients in the soil, as well as solar radiation, thus increasing tree growth [25]. However, different authors $[5,26,27]$ pointed out that there may be positive, negative or weak relationships between growth rate and wood density. Therefore, wood density has been recently described as a poor predictor of competitive ability among individuals of the same species [28].

In this sense, small reductions in wood density after thinning have been reported for several conifer species, including P. sylvestris [19,29], Pinus banksiana [30] and Picea abies [31]. Indeed, increased growth rate often decreases the density of earlywood and latewood [31]. On the other hand, an increase in wood density after thinning has been reported in Pinus taeda [32] and Pinus resinosa [33]. Generally, overall ring density may remain unaffected although thinning may influence the distribution and density of earlywood and latewood components within annual rings [29]. Such conflicting results arise because the effects of thinning on wood properties encompass many responses that may result in an increase, a decrease, or no effect on wood properties [5]. Such responses are a function of multiple factors such as growing conditions, site, initial stocking or age at time of treatment [34].

Given the need to explore the responses of ring width and density to thinning and their relationships with environmental factors, we selected a long-term thinning trial in Scots pine stands 
located close to its southwestern distribution edge (northern Spain), where drought stress has been found to affect radial growth [35]. Scots pine is one of the most important commercial conifer species in Europe and one of the tree species with the widest geographical distribution in the world [8]. Several studies have documented the influence of silvicultural treatments on radial growth and wood properties of Scots pine. For example, some authors suggested that it is possible to affect the uniformity of wood properties by thinning [36]. Other authors reported an important increase of mean ring width but not significant changes in density after thinning, while a negative correlation between ring width and density has also been found [29]. In the western Spanish Pyrenees, it was showed that light and moderate thinning weakly affected radial growth, which was enhanced three years after tree removal [35].

To better understand the relationships between forest management, environmental factors and wood properties, this study aimed to explore and compare the individual ring characteristics of trees in two Scots pine forests in northern Spain subjected to different climatic conditions for 14 years after different thinning treatments, using scanning X-ray densitometry. Both sites exhibit different water supply regimes (limiting vs. not limiting). Several tree-ring parameters (width and density among them) were retrospectively quantified at annual resolution using X-ray densitometry [5,37]. Ring characteristics are useful indicators in forest management and product manufacturing because they are strongly correlated with other tree traits, such as diameter growth and mechanical wood properties [5]. Some of these properties are related to intra-annual wood features (earlywood and latewood width and density, latewood percentage), which can be quantified using X-ray densitometric profiles [38]. Therefore, the effects of thinning intensity on different factors affecting wood density, such as latewood percentage, average ring density, and earlywood and latewood densities, were examined. Our specific objectives were: (1) to characterize ring characteristics (ring width and density variation) after different thinning intensity treatments; and (2) to analyze the effects of thinning and climate on wood growth and density in response to drought stress.

With those objectives in mind, we hypothesized that: (1) thinning will increase tree ring width and reduce wood density by releasing growth limiting factors for the remaining trees; (2) post-thinning growth response will be influenced by local soil and climatic conditions, expecting wider tree ring widths and lower wood density after thinning in the site with more intense combined growth limitations (water, nutrients, light and growing space); and (3) the thinning effect will not be beneficial under extreme drought conditions due to the cancellation of the positive effects on growth of increasing nutrient, light and growing space availability after thinning because of the extreme water limitation during drought events.

\section{Materials and Methods}

\subsection{Experimental Sites}

Our two experimental sites (Tables 1 and 2), are located in the higher river Ebro basin, south-western Pyrenees, near the towns of Garde and Aspurz in the province of Navarre (northern Spain). The study location in Garde represents an example of continental low-productive P. sylvestris forests in Spain. It is an even-aged stand resulting from successful regeneration after clearcutting by groups carried out during the early 1960s. The study location in Aspurz, a cool Mediterranean site, is an example of productive P. sylvestris forests in Spain. It is an even-aged stand resulting from successful regeneration after strip-like clearcutting carried out in the mid-1960s. Bedrock for both sites consists of flysch of sandstones and limestones. Differences in soil conditions and properties between sites are shown in Table 1. 
Table 1. Site features for both sites (mean \pm standard error).

\begin{tabular}{ccc}
\hline Variable & Cold Wet Mediterranean Site ${ }^{\mathbf{1}}$ & Cold wet Continental Site $^{\mathbf{1}}$ \\
\hline Name of nearest town & Aspurz & Garde \\
Latitude N & $42^{\circ} 42^{\prime} 31^{\prime \prime}$ & $42^{\circ} 48^{\prime} 50^{\prime \prime}$ \\
Longitude W & $1^{\circ} 08^{\prime} 40^{\prime \prime}$ & $0^{\circ} 52^{\prime} 30^{\prime \prime}$ \\
Altitude a.s.l. $(\mathrm{m})$ & 625 & 1335 \\
Mean slope $(\%)$ & 7 & 40 \\
Aspect & $\mathrm{N}$ & $\mathrm{NE}$ \\
Mean annual precipitation $(\mathrm{mm})^{2}$ & 895 & 1802 \\
Mean temperature $\left({ }^{\circ} \mathrm{C}\right)^{2}$ & 11.9 & 9.3 \\
Soil type (FAO) & Haplic Alisol & Dystric Cambisol \\
Texture (FAO) & Sandy loam & Clay loam \\
Maximum rooting depth & $45 \mathrm{~cm}$ & $35 \mathrm{~cm}$ \\
Saturated water content & $42.6 \%$ & $51.3 \%$ \\
Nitrogen content $(\% ;$ soil horizons A/B) & $0.31 / 0.15$ & $0.27 / 0.23$ \\
Organic Matter $(\% ;$ soil horizons A/B) & $11.69 / 1.14$ & $9.88 / 3.05$ \\
C/N ratio (soil horizons A/B) & $22.60 / 4.40$ & $22.00 / 7.70$ \\
\hline
\end{tabular}

${ }^{1}$ According to Papadakis classification [39]; ${ }^{2}$ Variables calculated for the period 1985-2014.

Table 2. Biometric traits for both sites (mean \pm standard error).

\begin{tabular}{|c|c|c|c|c|c|c|}
\hline Variable & \multicolumn{3}{|c|}{ Mediterranean Site } & \multicolumn{3}{|c|}{ Continental Site } \\
\hline Site index $(m)^{2}$ & \multicolumn{3}{|c|}{29} & \multicolumn{3}{|c|}{23} \\
\hline \multicolumn{7}{|l|}{ In 1999 (before 1st thinning) } \\
\hline Mean stand age (years) & & $32 \pm 4.3$ & & & $37 \pm 3.8$ & \\
\hline Treatment & T0 & T20 & T30 & T0 & T20 & T30 \\
\hline Tree density (trees ha ${ }^{-1}$ ) & $3517 \pm 681$ & $3811 \pm 340$ & $4820 \pm 491$ & $3555 \pm 358$ & $2933 \pm 268$ & $3202 \pm 135$ \\
\hline Mean height $(\mathrm{m})^{1}$ & $12.9 \pm 0.5$ & $12.9 \pm 0.4$ & $12.5 \pm 0.5$ & $10.9 \pm 0.4$ & $12.8 \pm 0.4$ & $13.3 \pm 0.1$ \\
\hline $\operatorname{Dbh}(\mathrm{cm})^{2}$ & $12.7 \pm 1.2$ & $11.6 \pm 0.4$ & $10.6 \pm 0.7$ & $13.3 \pm 0.7$ & $14.4 \pm 0.6$ & $13.7 \pm 0.12$ \\
\hline Mean basal area $\left(\mathrm{m}^{2} \mathrm{ha}^{-1}\right)$ & $42.3 \pm 2.0$ & $40.1 \pm 2.0$ & $41.6 \pm 1.2$ & $49.0 \pm 5.1$ & $47.4 \pm 0.7$ & $47.0 \pm 1.4$ \\
\hline \multicolumn{7}{|l|}{ In 2013 (tree coring) } \\
\hline Mean stand age (years) & & $46 \pm 2.3$ & & & $51 \pm 2.1$ & \\
\hline Treatment & T0 & T20 & T30 & T0 & T20 & T30/40 \\
\hline Tree density (trees ha ${ }^{-1}$ ) & $1456 \pm 156$ & $1125 \pm 83$ & $1078 \pm 147$ & $1552 \pm 280$ & $1286 \pm 93$ & $1164 \pm 49$ \\
\hline Mean height $(\mathrm{m})$ & $17.8 \pm 1.3$ & $18.1 \pm 0.8$ & $17.8 \pm 1.2$ & $14.7 \pm 0.7$ & $15.7 \pm 0.3$ & $15.2 \pm 0.2$ \\
\hline $\operatorname{Dbh}(\mathrm{cm})$ & $18.9 \pm 0.8$ & $19.9 \pm 1.3$ & $18.9 \pm 0.9$ & $14.9 \pm 0.9$ & $18.2 \pm 0.4$ & $18.7 \pm 0.2$ \\
\hline Mean basal area $\left(\mathrm{m}^{2} \mathrm{ha}^{-1}\right)$ & $40.9 \pm 1.4$ & $35.0 \pm 2.4$ & $30.4 \pm 1.5$ & $55.4 \pm 6.5$ & $53.3 \pm 1.3$ & $48.7 \pm 0.8$ \\
\hline
\end{tabular}

${ }^{1}$ Dominant height at 80 years; ${ }^{2}$ Mean diameter at breast height $(1.30 \mathrm{~m})$.

Both stands had similar site preparation and were naturally regenerated. European beech (Fagus sylvatica L.) abundance was relatively important in Aspurz (134 trees ha ${ }^{-1}$ with $\mathrm{dbh}>7.5 \mathrm{~cm}$ in 2013) but not in Garde. Climatic diagrams for the sites [40] for the last 30 years are shown in Figure 1. Historical climate data were obtained from the nearest weather stations to each study site (both at a distance of less than $5 \mathrm{~km}$ from each site). Due to the elevation difference between the continental experimental plots in Garde and the closest weather station (about $600 \mathrm{~m}$ ), climate data were adjusted using the MounTain microCLIMate simulation model (MT-CLIM) [41,42]. Maximum and minimum temperature lapse rates and precipitation isohyets needed for the extrapolation were calculated from regional climate data. Missing data were calculated by interpolating values from nearby weather stations. For the period 1985-2014, mean growing season (May-October) temperatures were $17.3^{\circ} \mathrm{C}$ and $15.0^{\circ} \mathrm{C}$, and precipitation amounts were $381 \mathrm{~mm}$ and $709 \mathrm{~mm}$ for the Mediterranean and continental sites, respectively (Figure 1). Summer droughts (periods of dry weather that persist long enough to cause tree growth reduction) are frequent at the Mediterranean site, with prevalent absence of rainfall during the summer period. 

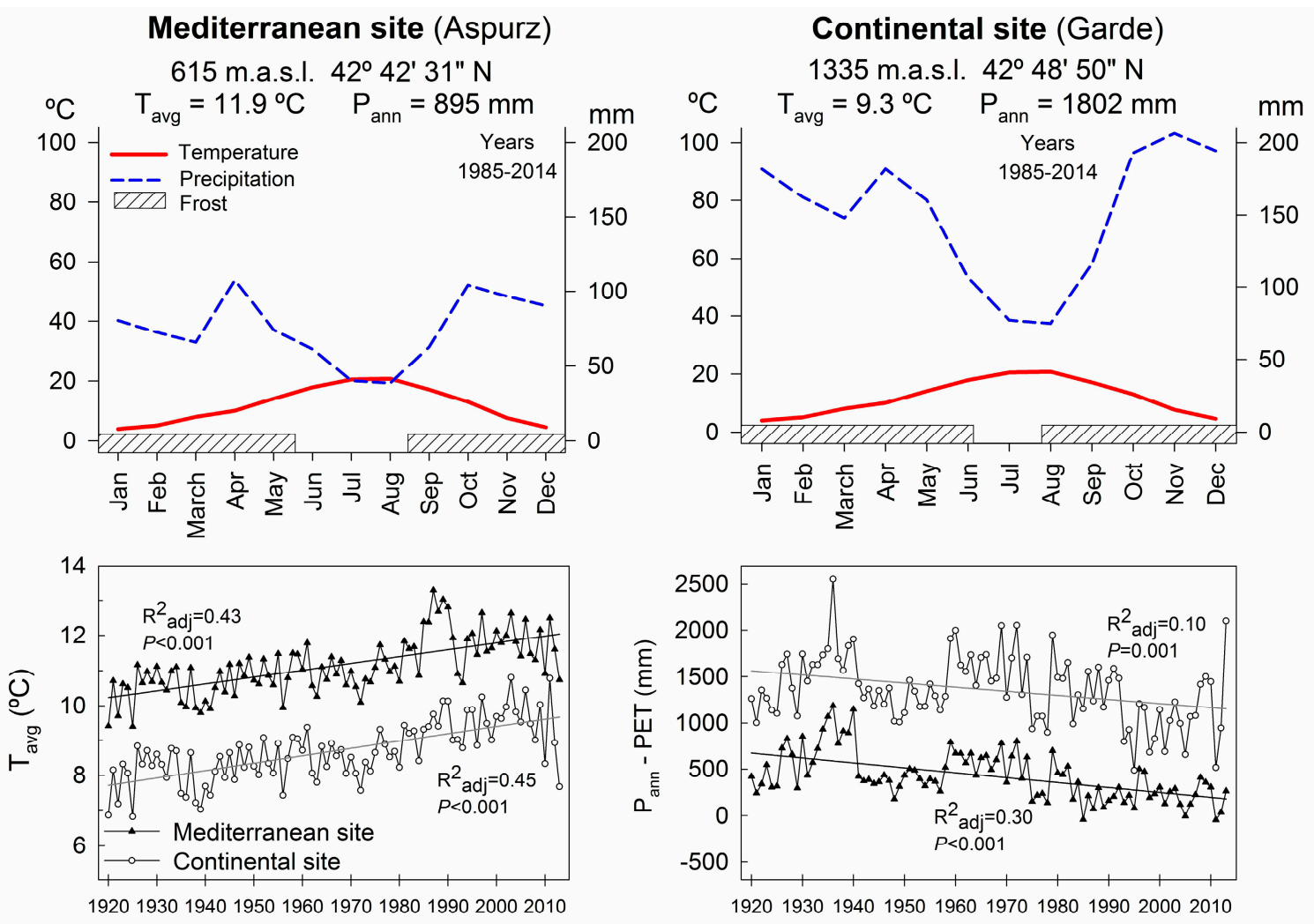

Figure 1. Top panels: Climatic diagrams for the Mediterranean (Aspurz) and continental (Garde) study sites considering the period 1985-2014. In the diagrams, Tavg is the mean annual temperature $\left({ }^{\circ} \mathrm{C}\right)$; Pann is the mean annual amount of precipitation ( $\mathrm{mm}$ ). Oblique striped areas (Frost) show months with an absolute minimum temperature below $0{ }^{\circ} \mathrm{C}$. Bottom panels: Variation of mean annual temperature (Tavg) and annual water balance, calculated as the difference between total precipitation (Pann) and potential evapotranspiration (PET), for the period 1920-2013 in the two study sites: Mediterranean site (black triangles) and continental site (open circles). Fitted lines for simple linear regression show climate trends (adjusted R-squared and $p$-values are presented in the graphs).

Temporal trends in annual and seasonal temperatures and water balance (P-PET) were calculated using linear regressions [43]. Since 1920, annual temperatures significantly rose $(p<0.001)$ at both study sites with a rate of $+0.020^{\circ} \mathrm{C}_{\text {year }}^{-1}$ (Figure 1). Water surplus showed a significant decreasing trend at both sites $(p<0.001)$, which was more pronounced in the Mediterranean site (Figure 1$)$.

\subsection{Experimental Design and Tree Sampling}

Nine experimental rectangular plots $(30 \mathrm{~m} \times 40 \mathrm{~m}$ ) per location were set up by the Forest Service of the Government of Navarre, following a complete randomized block design according to the guidelines of the International Union of Forestry Research Organizations (IUFRO) [44]. To avoid edge effects, the silvicultural treatment corresponding to each plot was also applied within a strip of 5-10 m adjacent to the plot. Thinning was carried out in August and November 1999 in Garde and Aspurz, respectively. Three treatments with three replicates (one of each treatment per block assigned at random) were established for each location (Table 2): (1) T0, reference with no thinning; (2) T20, moderate thinning from below ( $20 \%$ of basal area removed) with selection of crop trees, mainly removing suppressed trees and some dominant or codominant trees with malformed trunks; (3) T30, heavy thinning from below ( $30 \%$ of basal area removed) with selection of crop trees, removing suppressed and some intermediate trees, as well as some dominant or codominant trees with malformed trunks. The selected thinning regimes reflected typical silvicultural management schemes for Scots pine in this region $[19,36]$. Three different blocks were established by grouping the plots of each study area according to a management 
criterion but without taking into account ecological aspects. Logs and most branches from the felled trees were left outside plot limits. A second thinning was carried out in Aspurz in March 2009, repeating the same treatments in each plot but increasing the T30 treatment to $40 \%$ of basal area removed. To carry out the dendrochronological study, eight dominant trees were randomly selected in spring 2014 in each plot, for a total of 144 trees. Two increment cores per tree ( $5 \mathrm{~mm}$ wide) were extracted at dbh perpendicular to the maximum slope (pith to bark).

\subsection{Sample Processing}

All wood cores were extracted using 99\% methanol solution to remove the volatiles, and then mounted and cut with a precision saw in $1.6 \mathrm{~mm}$ wide radial slices for X-ray densitometric analyses at the Taiwan Forestry Research Institute (Taipei) in winter 2014-2015. An X-ray densitometer (QTRS-01X Tree-Ring Analyzer, Quintek Measurement Systems (QMS), Knoxville, TN, USA) was used on the slices (cores) to determine their ring characteristics. Each slice was scanned and moved through the X-ray machine in the radial direction. A detailed description of the machine and how it works can be found in QMS [45] and Lin et al. [23].

The QMS Tree-Ring Analyzer determines the absorption of radiation from a collimated beam of $\mathrm{X}$-rays of a narrowly controlled energy range. That absorption is related to the actual sample density by basic radiation attenuation principles. The minimum and maximum density method uses the minimum and maximum density of the densitometry profiles of individual annual rings [46]. Based on the density profiles, the early-latewood boundary in each ring was defined by an average of both the maximum (Dmax) and minimum density (Dmin) in the ring. Earlywood was defined as the lighter-colored component of the annual ring when visually comparing, and its end is characterized by an abrupt transition to latewood [47].

Studied ring characteristics included: average tree ring width (RW), basal area increment (BAI), earlywood width (EW), latewood width (LW), ring density (RD), earlywood density (ED), latewood density (LD), maximum density (Dmax), minimum density (Dmin), and latewood percentage (LWP). All specimens reached moisture contents (MC) of approximately $12 \%$ and the wood density value (weight at $12 \% \mathrm{MC} /$ volume at $12 \% \mathrm{MC}$ ) was adopted when the ring density components were converted from the degree of $\mathrm{X}$-ray absorption. All samples were visually cross-dated using the identification of signature years. Cross-dating quality was validated using the program COFECHA [48], by moving correlations between individual series and a reference mean series or site chronology. The trend of decreasing ring width with increasing tree size was removed by converting ring width into BAI using the formula $B A I=\pi\left(r_{t}^{2}-r^{2}{ }_{t-1}\right)$, where $r$ is the tree radius and $t$ is the year of tree-ring formation. Average series inter-correlation and mean sensitivity were 0.532 and 0.213 for the Mediterranean site, and 0.507 and 0.178 for the continental site.

\subsection{Statistical Analyses}

Relative changes between the pre- and post- first thinning periods for the selected tree ring features were computed for each individual tree, and significant differences among treatments were tested using Tukey's honest significant difference (HSD). At the Mediterranean site, differences between the post-first thinning and post-second thinning periods were analyzed in the same way. Research sites were coetaneous stands, (all sampled trees have roughly the same age, Table 2); hence, the age effect was not considered relevant. Pearson's correlation coefficients between the Standardized Precipitation Evapotranspiration Index (SPEI) [49] calculated at a time scale of 24 months and BAI, LW, RD and Dmax were used to explore the influence of drought on tree ring features for the same two/three different periods (10 years of pre- and post-thinning periods at the continental site, and 10 years pre-first thinning, 10 years post-first thinning and 4-years post-second thinning at the Mediterranean site). Pearson's correlation coefficients between tree ring width and density were also computed for each pair of related attributes (i.e., RW vs. RD, EW vs. ED, and LW vs. LD) separately for each site. Differences between levels of each factor were considered statistically significant when the $p$-value 
was lower than 0.05 . Statistical analyses were performed using Statgraphics Centurion $\mathrm{XVI}^{\circledR}$ software (Manugistics Inc., Rockville, MD, USA) and JMP version 12.0 (SAS Institute, Cary, NC, USA).

\section{Results}

\subsection{Influence of Thinning Intensity on Ring Width}

Significant differences among treatments were not observed for width components (namely BAI, RW, EW, LW and LWP) before and after the first thinning in 1999 at the Mediterranean site (Figure 2). Conversely, significant differences for these variables were observed between trees from unthinned (T0) plots and those from moderate (T20) and/or heavy (T30/40) thinned plots after the second thinning, although differences between T20 and T30/40 were not significant. Furthermore, a general decrease in ring width attributes (BAI, RW, EW, LW) was detected in T0 plots, whereas the average BAI, RW, EW, and LW of the rings formed after the second thinning of trees sampled at thinned plots were significantly higher, especially for the heavily thinned (T30/40) plots (Figure 2).

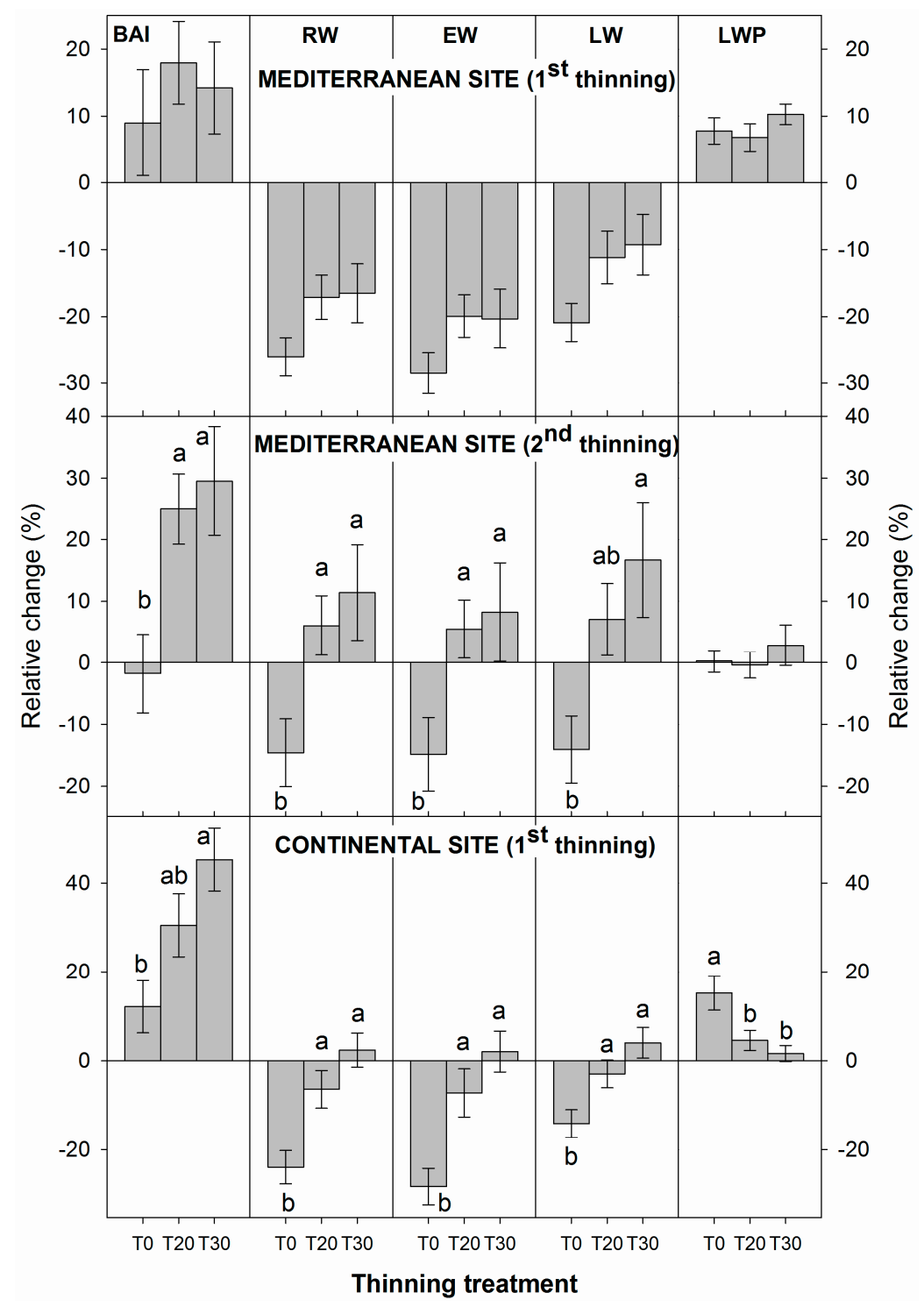

Figure 2. Average relative changes in width-related attributes in individual trees comparing the 10-year periods before and after the $1^{\text {st }}$ thinning event and 4 years after the second thinning event at the Mediterranean site. Different letters indicate significant differences $(p<0.05$; Tukey's HSD test). 
Similarly, at the continental site, average width values increased significantly in the thinned plots (T20 and T30) compared to the unthinned (T0), with differences between T20 and T30 not significant. Significant BAI, RW, EW and LW reductions were also detected for T0 plots. LWP change relative to the pre-thinning period was significantly higher in the heavily thinned plots than in the T0 or T20 plots (Figure 2).

At the Mediterranean site, higher EW, LW and RW values were found eight years (2007) after the first thinning but just 2-5 years (2010-2013) after the second thinning event. Thinning also caused wider LW in the first year (2009) after the second thinning event (Figure 3). At the continental site (Garde), there were no significant differences between thinning treatments in the years after thinning was performed.

Analysis of each year after thinning and comparison of the average LWP of Scots pine trees from thinned and unthinned plots indicated that thinning at the Mediterranean site did not cause significant differences among treatments (Figure 2). However, at the continental site, significantly higher LWP was observed when thinning plots were compared to unthinned plots (Figure 2).

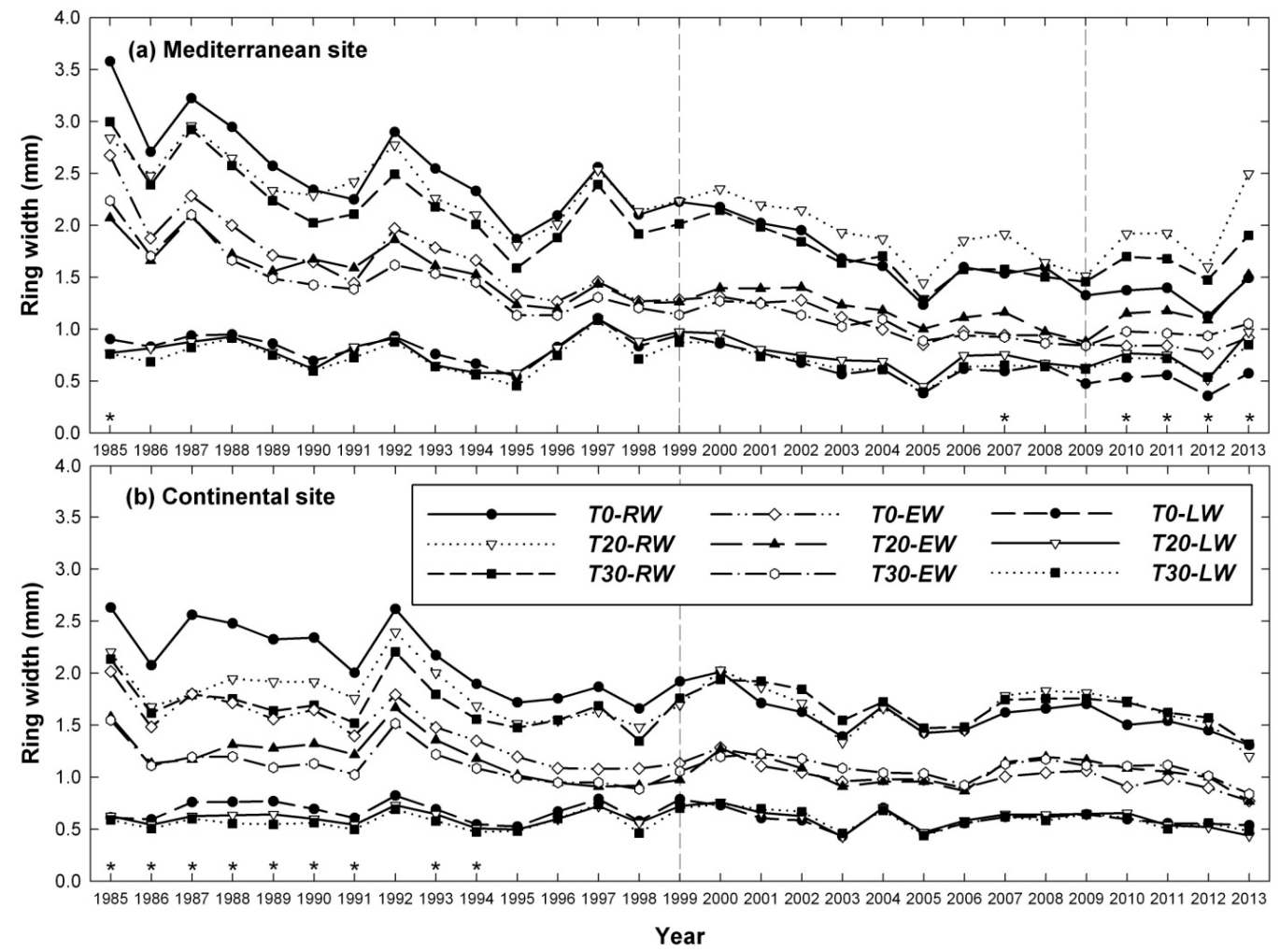

Figure 3. Temporal variation in ring-width components (mm) from 1985 to 2013 of Scots pine trees sampled in thinned (T20, T30) and unthinned (T0) plots, at both Mediterranean (a) and continental (b) sites. The vertical dashed lines indicate the 1999 and 2009 thinning treatments and stars $\left({ }^{*}\right)$ indicate the years with significant RW differences among thinning treatments. Significant differences for EW and LW among thinning treatments are described in the main text.

\subsection{Influence of Thinning Intensity on Wood Density}

At the Mediterranean site, no significant relative changes in values of density attributes were observed between thinning treatments after the first thinning in 1999 (Figure 4). However, changes in density attributes after the 2009 thinning were significantly less pronounced in thinned than in unthinned plots. Thus, the average relative changes in LD and Dmax components were significantly smaller in the unthinned plots than in the T30 plots. In contrast, at the continental site, average 
RD values increased relatively more in the T0 plots compared to the thinned plots (T20 and T30). Significant relative reductions in ED were also detected for T20 and T30 plots.

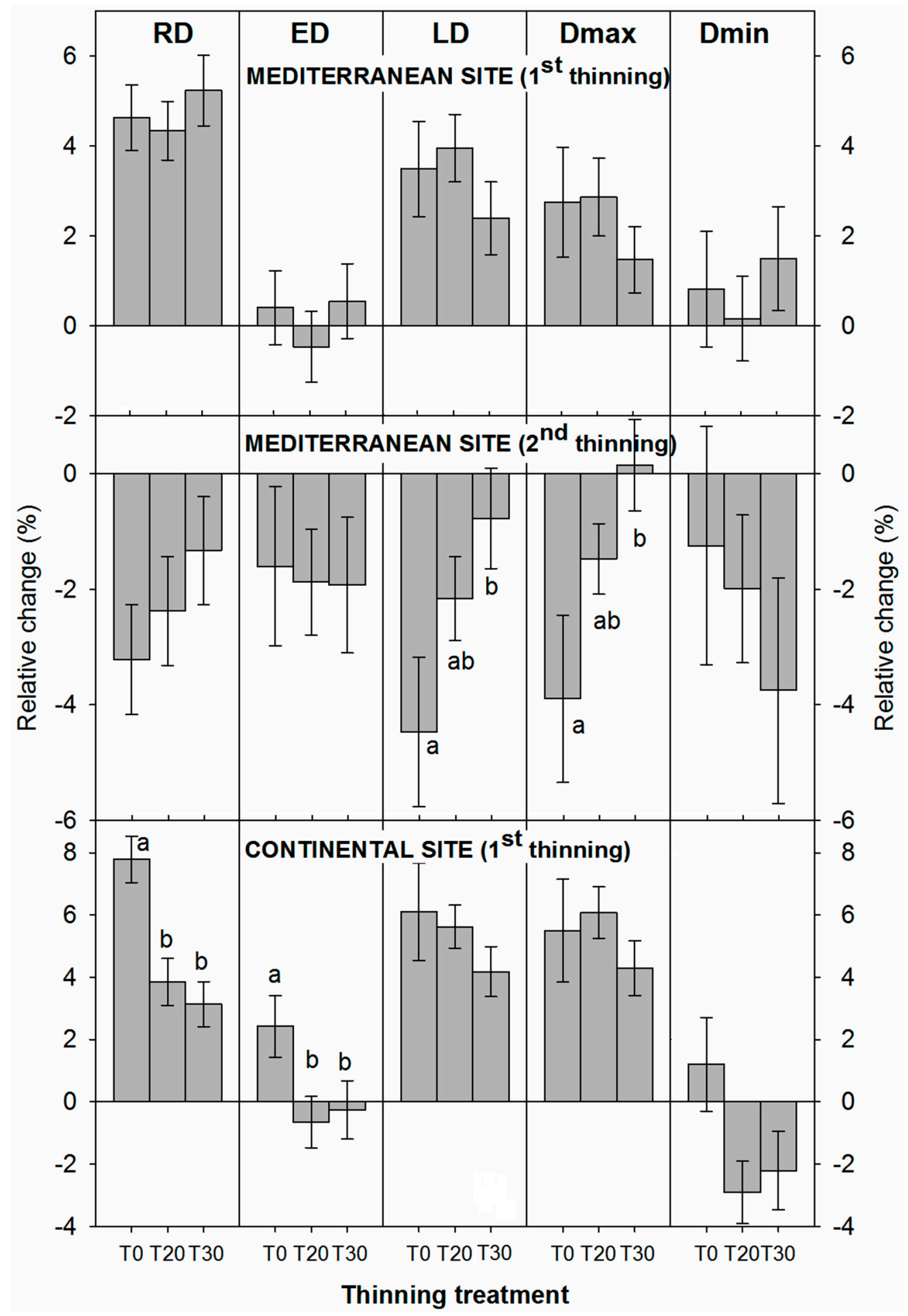

Figure 4. Average relative changes in density-related attributes in individual trees comparing the 10 -year periods before and after the 1st thinning event and 4 years after the second thinning at the Mediterranean site. Different letters indicate significant differences $(p<0.05$; Tukey's HSD test).

When individual years were analyzed, heavy thinning (T30/40) at the Mediterranean site caused the production of significantly higher RDs in the 2002-2003, and 2008-2012 periods, when compared 
to moderately thinning or control (Figure 5), but significant differences were also observed in some years before thinning (1990-1993, 1996-1997, and 1999). At the Mediterranean site, larger ED values were observed in the T30 plots in the second year after first thinning in 1999, and in the 2003-2005 and 2008-2010 periods. Significantly larger LD and Dmax were found in the T30/40 plots in the years 2010 to 2012 (after the second thinning). Heavy thinning (T30) also led to larger Dmin values, i.e., more narrow earlywood tracheid lumens, in the 2nd (2001) and 5th (2004) years after the first thinning. Contrastingly, at the continental site, thinning did not produce any significant differences in ring density attributes among treatments. Taken together, these results indicated that the wood density components (RD, ED and Dmin, LD and Dmax) had different reactions to thinning at the Mediterranean site in terms of the durability of the response and the years affected.

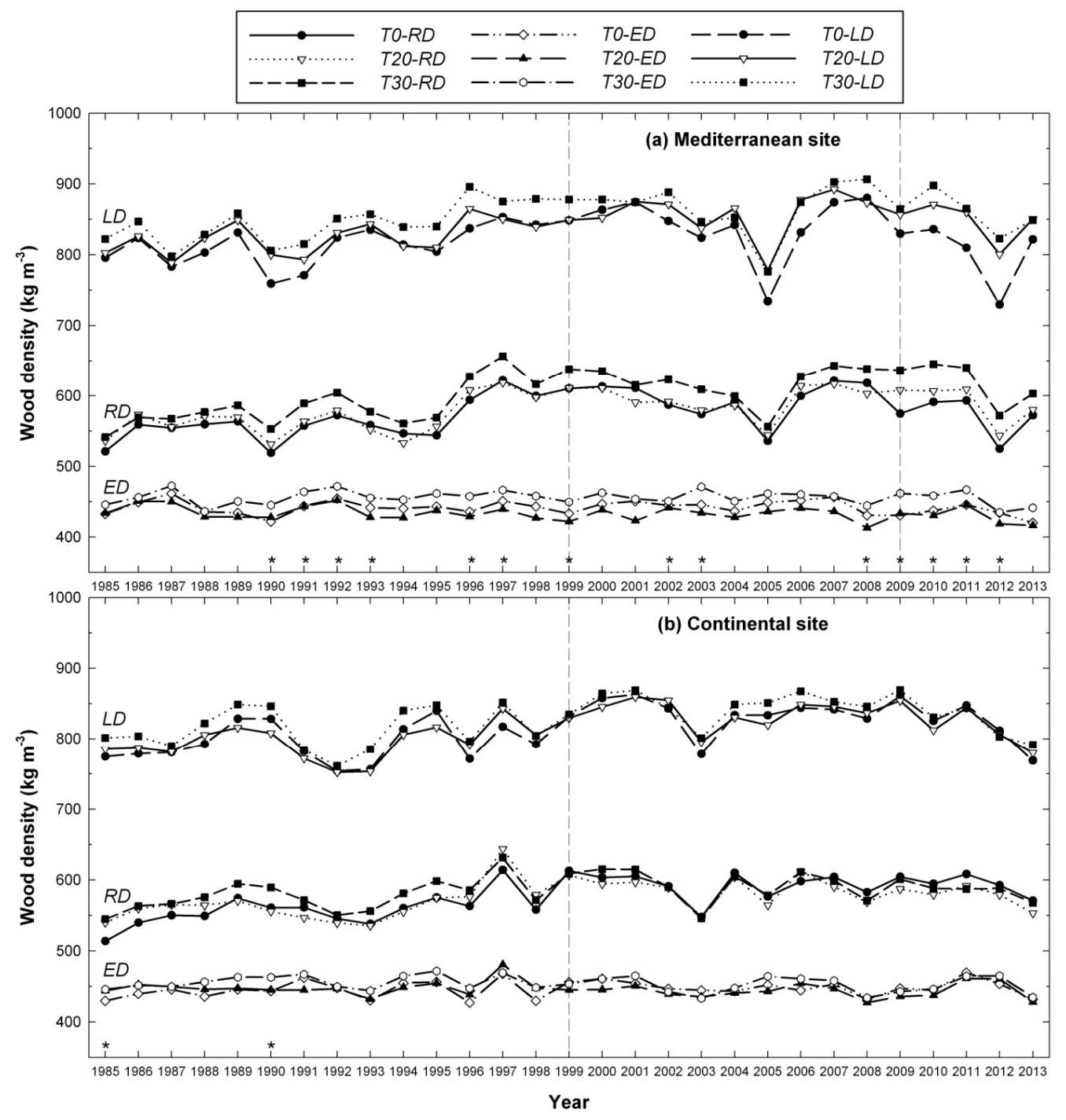

Figure 5. Changes in ring wood density $\left(\mathrm{kg} \mathrm{m}^{-3}\right)$ from 1985 to 2013 of Scots pine trees sampled at thinned (T20, T30) and unthinned (T0) plots, at both Mediterranean (a) and continental (b) sites. Vertical dashed lines indicate the 1999 and 2009 thinning treatments and stars $\left(^{*}\right)$ indicate the years with significant differences of RD among treatments. Significant differences for EW and LW among thinning treatments are described in the main text.

At both sites, the annual variation in ring density was high, but the general trend within sites for RD and LD was similar. At the Mediterranean site, before thinning was carried out, a remarkable decrease of ring density occurred in 1990, as well as a significant density increase in 1997 followed by 
a significant decrease the year after. Then, two significant reductions of ring density occurred in 2005 and 2012 affecting all trees (i.e., 6 and 3 years after the first and second thinning, respectively). However, significant reductions of ring density in 2002 and 2009 affected only unthinned plots (Figure 5). At the continental site and similar to the Mediterranean site before thinning, a significant increase of ring density occurred in 1997 followed by a significant decrease in 1998. A significant reduction of ring density occurred the 4th year after thinning (2003) affecting all trees, and two years later (in 2005) another reduction was detected affecting significantly only T20 and T0 plots. Conversely, a third decrease of ring density in 2008 was more pronounced in the T30 plots.

\subsection{Interacting Effects between Climate and Thinning on Wood Features}

Significant relationships between tree ring features and the SPEI drought index at a 24-month scale were found at the Mediterranean site for all the treatments and periods (before and after thinnings, Figure 6). However, for the continental site, correlations were much weaker and no significant correlations were found after thinning, although pre-treatment significant correlations were found for BAI (T20) and LW (T20, T30) (Figure 6). At the Mediterranean site, the second thinning treatment influenced the strength of the relationship between climate and ring width, particularly for the T20 plots, although the effects on ring density were not clear. On the other hand, at the continental site, thinning seems to have removed the pre-thinning climatic significant influence on BAI (T20) and LW (T20 and T30), but no clear effects were found on the interaction between climate and density (Figure 6).

To characterize the temporal changes in the strength of thinning effects on ring width, the relative change in annual RW, EW, and LW values after thinning was compared to the average before the 1999 thinning (Figure 7). At the Mediterranean site, a clear general reduction in RW, EW and LW values after thinning were detected, with the highest reductions observed in dry years such as 2005 and 2012. At the continental site, a slight increment in the ring-width components was observed in thinned plots (T20, T30) during a couple of years after thinning (Figure 7). The unthinned (T0) plots also showed increased LWs during the 2007-2010 period. At this site, the largest reductions were observed in 2003, 2005 and 2013.

The relative change in RD, ED and LD after the 1999 thinning was also studied in thinned plots (T20, T30) and unthinned plots (T0) (Figure 7). At the Mediterranean site, an average reduction (including the three treatments) of 5.1\% and 4.9\% in RD was detected in 2005 and 2012, respectively, in comparison to pre-thinning values. This decrease in wood density was mainly due to reductions in $\mathrm{LD}(8.0 \%$ and $5.4 \%$ in the same years, respectively). At the continental site, an average RD reduction of $3.9 \%$ was detected in 2003 in the three treatments, whereas the relative reduction in RD in years 2005, 2008 and 2013 was only observed in the thinned plots. Additionally, there was a reduction of $0.2 \%, 1.4 \%$ and $2.0 \%$ in RD in 2005, 2008 and 2013, respectively, for heavily thinned plots, and we also observed a reduction of $0.5 \%$ and $2.6 \%$ in 2005 and 2013, respectively, for moderately thinned (T20) plots. This decrease in RD was favored by reductions mostly in LD and ED. Regarding LD, an average reduction of $1.4 \%$ and $2.8 \%$ was detected in 2003 and 2013 respectively, whereas there was an even higher reduction in ED (2.6\% and $4.1 \%$ in 2003 and 2013, respectively) compared to values before thinning. The highest average ED reduction (4.2\%) was detected in 2008 including the three treatment conditions.

At both sites, ring width was negatively correlated with ring density $(r=-0.2370, p<0.0001$ for the Mediterranean site, $r=-0.3646, p<0.0001$ for the continental site), and also earlywood width with earlywood density $(r=-0.2061, p<0.0001$ for the Mediterranean site, $r=-0.3669, p<0.0001$ for the continental site). No significant correlations between latewood width and latewood density were found ( $r=0.0051, p=7510$ for the Mediterranean site, $r=-0.0192, p=2945$ for the continental site). 


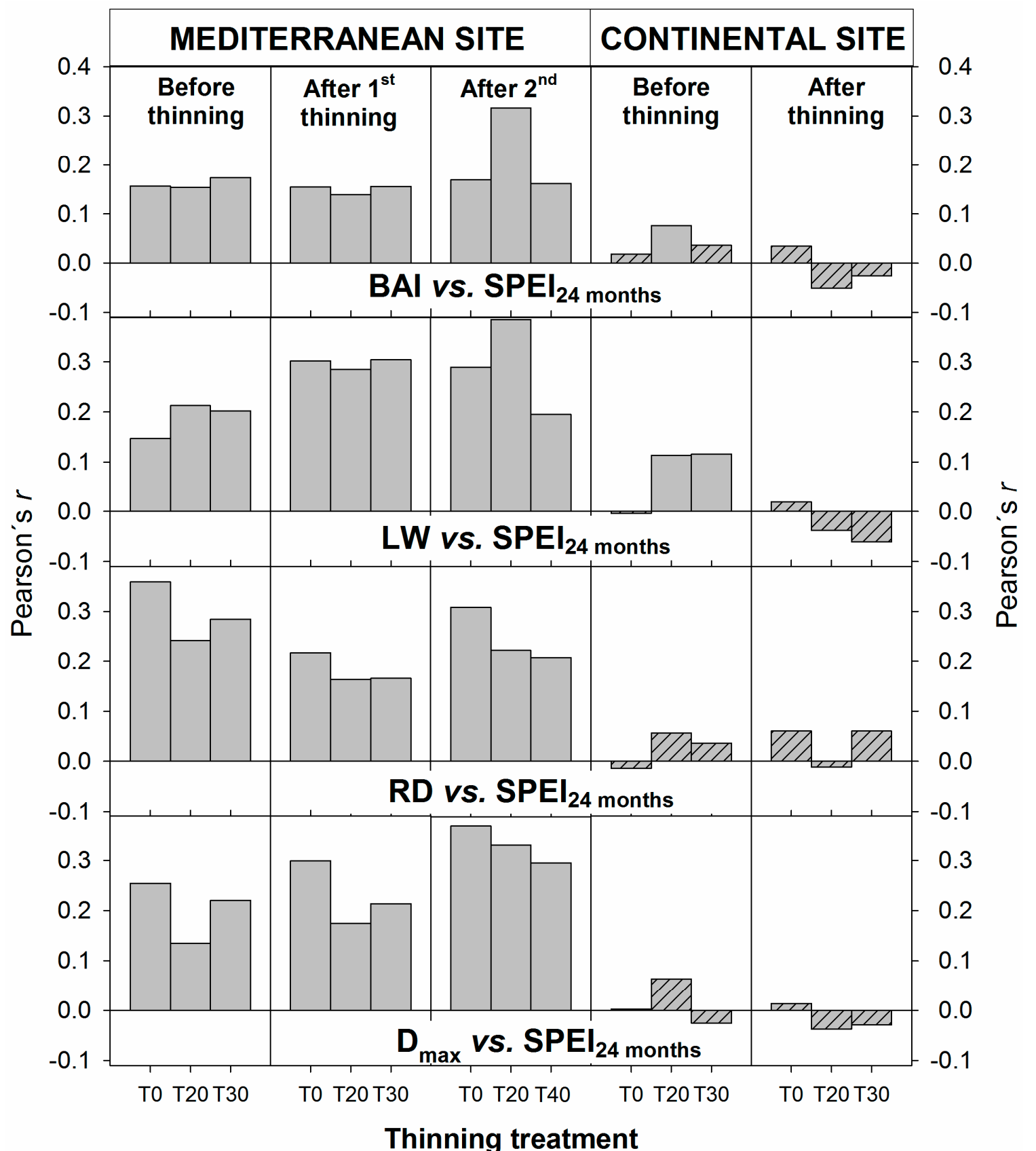

Figure 6. Pearson's $r$ coefficients for the correlation between tree ring features and climate for thinning treatments (T0, T20 and T30/40) for three periods (before thinning, after first thinning and after second thinning) at the Mediterranean and continental sites and two periods at the continental site (before and after thinning). Stripped bars represent non-significant correlations at $\alpha=0.05$. 


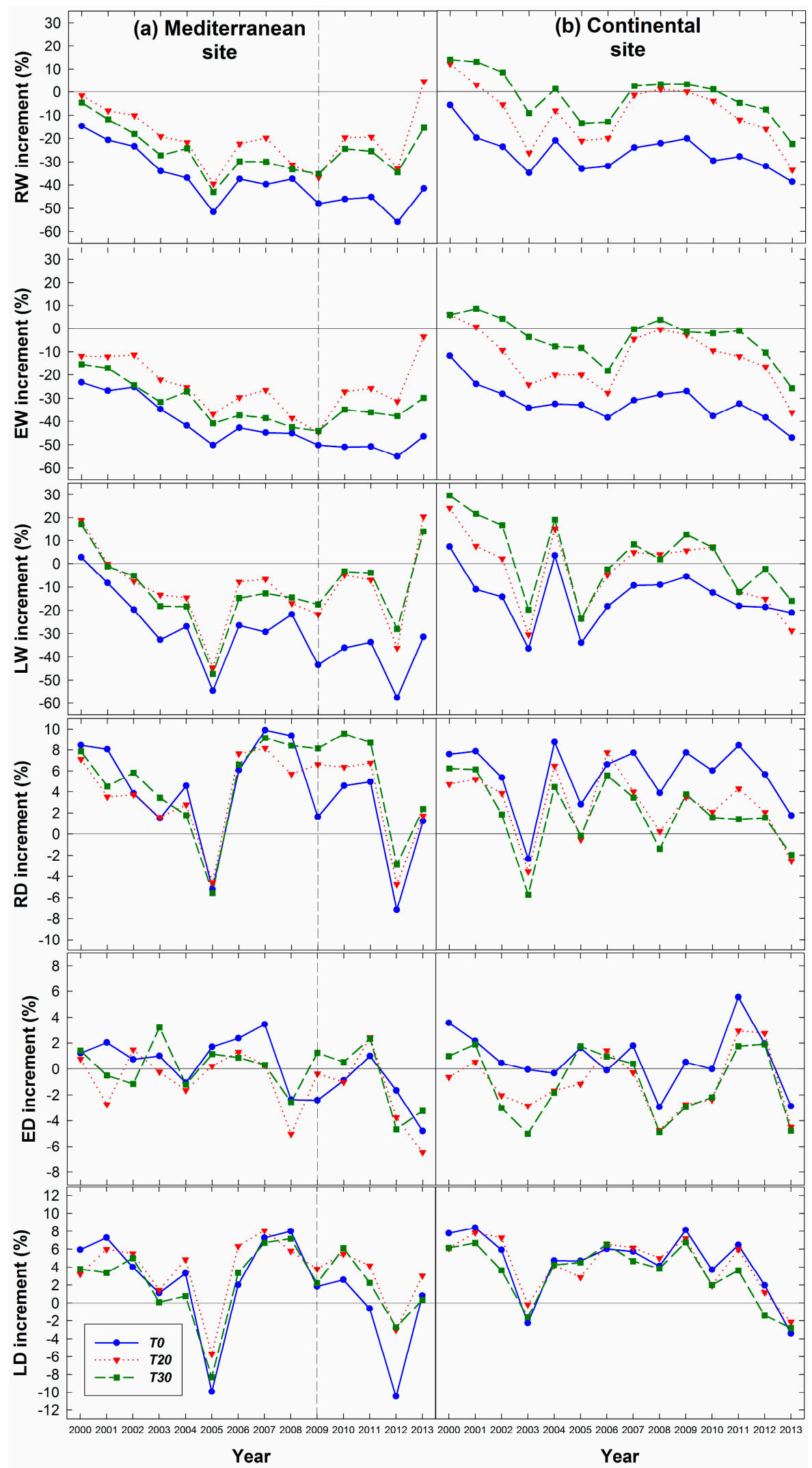

Figure 7. Relative changes of ring-width components and ring-density components with respect to the average values obtained before the 1999 thinning (1985-1999 period) of Scots pine trees from thinned (T20, T30/40) and unthinned plots (T0), at both Mediterranean and continental sites. The dashed line in the Mediterranean site indicates the time of the second thinning. 


\section{Discussion}

One of the aims of this study was to analyze the effects of thinning intensity on wood growth and density of Scots pine over a period of 14 years after the first thinning in naturally regenerated stands. Scots pine is a useful species in dendroecological studies since its radial growth clearly responds to environmental factors including drought stress [50,51]. It is widely known that thinning affects growth and wood properties, while the positive effect on tree diameter depends on the thinning regime [52]. Moreover, the thinning response and its dependence on changes in growing conditions provide highly relevant information for use in practical forest management, potentially allowing optimizing the timing and intensity of thinning [36].

Our results support our first hypothesis that thinning enhanced radial growth (higher BAI, RW, EW, and LW values) as compared to unthinned plots. However, the effect of thinning intensity at the Mediterranean site depended on the frequency management interventions. Thus, the first thinning had no effect on radial-growth attributes but the second thinning did. In fact, effects of the second thinning on radial-growth attributes in the Mediterranean stand (Aspurz) were similar to the corresponding effects of the first thinning at the continental site (Garde). The absence of significant thinning effects on growth at the Mediterranean site might be due in part to the fact that the stand structure was initially highly variable among plots [35]. Additionally, such differences in effects by the first thinning between sites could indicate a stronger nutrient limitation at the continental site (as previously reported for the same stands, [53,54]), despite a higher water limitation at the Mediterranean site [43]. Although the Mediterranean site has a sandy texture that retains slightly less water than the continental soil, its soil is also deeper, and as a consequence both study sites show similar water retention capabilities. This indicates that difference in water limitation are due to water supply, rather than soil water retention capacity.

Our results also indicated that diameter growth at both sites increased more substantially in the heavily and moderately thinned plots than in the unthinned plots, although differences between T20 and T30/40 were not significant. Most research supports that thinning treatments increase annual ring widths [23,29,55], but the positive effect on tree diameter depends on the thinning regime [52]. Some authors indicate that the increase in diameter growth immediately after thinning in Scots pine stands was most marked in the heavily thinned plots [36]. Other authors found that radial growth increased more on heavily thinned plots than on less intensively thinned or unthinned plots in Pinus taeda [56,57]. Similar observations were made for P. abies [58] and in P. sylvestris [59]. Moreover, thinning is proven to improve the recovery of radial growth following drought in Scots pine [60]. In this study, a trend for larger LWP was only observed for T30/40 plots at the Mediterranean site. Similar to this result, a moderate thinning treatment produced higher LWP than other treatments in Mediterranean stands of Pinus brutia [55]. Furthermore, this author described significant positive relationships between RD and LWP from unthinned and thinned stands. Other researchers have also indicated that thinning could increase latewood growth, leading to increased wood density [5]. Effects of the second thinning on the ring-width attributes at the Mediterranean site occurred much faster than after the first thinning, suggesting faster crown development after the second thinning.

A general decrease in values of density attributes relative to pre-thinning conditions was observed after the second thinning at the Mediterranean site (Aspurz). On the contrary, all these values increased after thinning at the continental site (Garde). Such a density reduction pattern in Aspurz might be related to a more pronounced decreasing trend over time as a result of water surplus at this site (see Figure 1). Nevertheless, the thinning effect on ring density was stronger at the continental site, a fact that did not support our second hypothesis. Similar to our results, other studies have reported contradictory results on the effects of thinning on wood density. Different authors stated that thinning has little or no effect on wood density $[5,29,55]$. On the other hand, other researchers concluded that thinning resulted in increased growth and a slight reduction in wood density [31], or suggested that wood density is reduced by thinning treatments [61,62]. Moreover, some reports have shown that thinning treatments can cause an increase in wood density [63,64]. 
Indeed, heavy thinning caused significantly higher ring densities (RD) in various periods (i.e., 2002-2003, 2008-2012) and larger RWs were found after moderate thinning (i.e., 2007, 2010-2013) at the Mediterranean site, as previously reported for RW changes in the same study area [35]. Conversely, the same thinning treatments did not produce any significant changes at the continental site. In this way, the second thinning treatment carried out in the Mediterranean site led to RD and RW increases. However, thinning treatments did not cause immediate increments of RW nor RD in the first year after thinning.

Tree responses to environmental conditions occur at seasonal temporal scales [2]. For instance, drought events during the growing season can trigger remarkable changes of wood density [65], and can even induce adult tree death as a consequence of long or intense events [66]. Estimation of drought events impacts on Scots pine growth thus becomes important considering that previous studies in Spain have demonstrated that Scots pine displays the highest mortality rate among several pine species under severe droughts $[67,68]$. Particularly severe droughts in some specific years after the thinning treatments were observed during the studied period.

Although the results revealed differences between study sites in annual changes, important decreases in ring width were found for similar years (2005 and 2012-2013). Similarly, the driest and warmest years on record at both sites after the first thinning was applied were 2003, 2005, 2011 and 2012, with 2011 also being the driest year since 1920 at both sites (Figure 1). At both study sites, a significant and common reduction of RD and RW occurred in 2003, 2005 and 2012. The 2003 heat wave is considered proof of the global warming effects on European productive systems including agricultural and forestry sectors [69]. For instance, in northern Spain, 2003 was one of the warmest years at both study sites during the last 50 years. At the Mediterranean site, 2005 and 2012 showed a rainfall decrease of $24.8 \%$ and $21.2 \%$, respectively, compared with the mean annual precipitation. However this effect was significantly more pronounced at the continental site, where a higher temperature variation was observed for that year. At the continental site, an increase of 32.4\% in mean temperatures was detected in 2003, which was observed as the warmest year during the studied climatic series. In addition, a rainfall decrease of $27.5 \%$ compared with the mean annual precipitation was recorded in 2005, which was also considered one of the driest years during the study period (Figure 1).

Moreover, anomalous ecophysiological reactions have been reported in several tree species after those heat waves [65]. For example, the 2005 and 2012 droughts have been also reported as some of the most important dry spells affecting Mediterranean Spanish forests [70], particularly because they followed previous years that were also drier than usual. At the continental site, an important decrease of RD and RW occurred during 2012-2013. In this sense, Primicia et al. [35] indicated that the 2005 drought might have cancelled out the effects of thinning on growth because an abrupt growth reduction was observed in trees from the Mediterranean site. Water stress promotes a strong reduction in stomatal conductance, together with an enhancement of respiration rates and a decrease in the stored C pool [71], eventually leading to decreased growth. One of the main consequences of these drought and heat waves for the trees was not only a dramatic reduction in growth, but also lower ring density, as a response to a reduction in soil water availability [66]. This is consistent with the production of less dense latewood tracheids, less lignified and with wider lumen areas and narrower cell walls leading to a more effective water-conducting (albeit more vulnerable to cavitation) hydraulic architecture [72]. Thinning influenced the relationship between climate and ring width at the Mediterranean site, and also eliminated the pre-thinning climatic significant influence on growth at the continental site. In addition, we found a significant influence of drought on wood density only at the Mediterranean site. Scots pine, as a water stress avoider, can close stomata during the critical insolation hours of the hottest days [73]. In addition, lowering LD during exceptionally dry years could have been an adaptation to autumns with scarce water availability following dry summers, as experienced at our sites during the last 20 years.

For the period before thinning was carried out, the driest years at the Mediterranean site were 1989 and 1993, and the warmest year was 1997. One year after each of these climate extremes, 
a drop in wood density was found (Figure 5). Similarly, at the continental site, 1993 and 1998 were the driest years before thinning (Figure 1), also coinciding with significant drops in ring density (Figure 5). However, our results are in contrast with previous reports on dry spring conditions leading to denser earlywood, theoretically characterized by narrower lumen tracheids, as has been observed in Spanish juniper (Juniperus thurifera, [6]). Such contradictory results could be explained because dry spells and heat waves lead to abrupt changes in wood phenology and water use, causing the enlargement of water-conducting cells even if growth is reduced [72]. Previous research indicated that trees surviving heat and drought waves have a significantly higher mean ring density, i.e., they form tracheids with more narrow lumens less susceptible to embolism [2]. Our results could indicate that trees under water stress face a complicated balancing act: they could adapt to severe drought by reducing hydraulic resistance during that year (lowering RD), but the increased embolism risk may force trees to quickly increase RD the year after (Figure 7). As these extreme drought events are becoming more frequent under the general scenario of climate change [74], it should also be expected an increase in variation in temperatures and precipitation. In this context, previous and recent studies in northern Spain already suggested that the decrease in rainfall and the increase in mean temperature (and therefore evapotranspiration) must be considered as the most important factors that will affect growth of the Scots pine [50,75]. Therefore, greater fluctuations in Scots pine wood density are to be expected. Consequently, a great natural variability could appear in terms of wood density, strength, and appearance because of the wide range of growth conditions for the trees, affecting pine wood's potential for different uses and its economic value [12].

In this study, moderate or heavy thinning treatments generally enhanced Scots pine radial growth, as the results showed that average ring width values increased significantly in the thinned plots (T20 and T30/40) compared to the unthinned (T0), although two thinning events were needed at the Mediterranean site to reach such an effect, whereas at the continental site, one thinning event was enough to cause significant differences among treatments. However, a general decrease of density attributes was detected after the second thinning at the Mediterranean site, whereas an increase in these values was observed at the continental site. The dynamics over time of such effects depended on site and thinning treatment and were modified by droughts and heat waves, supporting our third hypothesis. These results demonstrate the complex interactions between site, management and climate. Moreover, our results indicate that there were significant, albeit weak, relationships between width and density attributes in Scots pine trees at the two study sites, as indicated by other authors [23]. This fact agrees with the review which shows that growth rate is one of the many factors that can influence wood density [5]. In general, thinning effects on ring density are smaller than effects on ring width [29]. Several researchers have found different relationships between tree ring growth and density. Some authors reported that RD generally tends to decrease with increasing RW [61]. Other authors also stated a negative relationship between annual growth rate and wood density in Scots pine [8,29]. It has also been reported that wood density is not significantly influenced by growth rate [76], and that wood density is independent of the growth rate [77]. As a consequence, it is increasingly challenging to predict the effect of future thinning on wood mechanical properties of these forests.

\section{Conclusions}

Warm and dry climatic conditions significantly reduced ring width and density, suggesting Scots pine's capacity to enhance hydraulic conductivity during summer droughts. The capacity of thinning to alter water availability and therefore regulate the growth process is not enough to prevent drought-induced changes in wood properties. Our results support the view of fluctuating influences on the process of wood density formation, related mostly to climate extreme events but that can be influenced to some extent by forest management. Although in regular years wood density seems to have fluctuations smaller than the effect caused by thinning, the influence of unusually dry and hot years can override such management influence. On the other hand, thinning can also reduce such fluctuations. Our results indicated the viability to use thinning as a tool to adapt forests to climate 
change extends not only to radial growth [16], but also to wood density. Such climate effects on wood density are also site-dependent, depending not only on the total yearly precipitation but also on its seasonality, and their interactions with other growth-limiting factors, as the rejection of our second hypothesis implies. With the expected future climate becoming both drier and more variable in this region, future evolution of wood density in Scots pine forests in the southern edge of its continental distribution could be increasingly variable, and forest management could lose its capacity to influence it by modifying stand density.

Acknowledgments: The authors wish to thank Gabriel Sangüesa-Barreda for his assistance with the field sampling. We would also like to thank the Taiwan Forestry Research Institute for its full support and free access to the X-ray densitometer and related materials during the sample processing and measuring period. Finally, we want to thank the Editor and Reviewers whose comments helped to greatly improve this paper. E.G.A. was funded through a Spanish Predoctoral Research Grant (ref. BES-2013-066705). Funding for this research has been provided by the Spanish Ministry of Economy and Competitiveness (project AGL2012-33465), which also funded Y.-H.L. J.A.B. was funded through a Ramón y Cajal contract (ref. RYC-2011-08082) and a Marie Curie Action (ref CIG-2012-326718-ECOPYREN3), which also funded D.C.-P. Funds to cover the costs of publishing in open access were provided by the OpenAIRE pilot program of the European Union 7th Framework Programme.

Author Contributions: J.A.B. and Y.-H.L. conceived and designed the experiments; J.J.C, Y.-H.L., J.A.B., and E.G.d.A. performed the experiments; J.J.C., C.-M.C. and F.J.C. contributed reagents, materials and analysis tools; D.C.-P., Y.-H.L. and J.J.C. analyzed the data; D.C.-P., J.B.I., J.A.B. and J.J.C. wrote the paper.

Conflicts of Interest: The authors declare no conflict of interest. The founding sponsors had no role in the design of the study; in the collection, analyses, or interpretation of data; in the writing of the manuscript, and in the decision to publish the results.

\section{References}

1. Fritts, H.C. Tree Rings and Climate; Blackburn Press: Caldwell, NJ, USA, 2001.

2. Martínez-Meier, A.; Sánchez, L.; Pastorino, M.; Gallo, L.; Rozenberg, P. What is hot in tree rings? The wood density of surviving Douglas-firs to the 2003 drought and heat wave. For. Ecol. Manag. 2008, 256, 837-843. [CrossRef]

3. Vaganov, E.A.; Hughes, M.K.; Shashkin, A.V. Growth Dynamics of Conifer Tree Rings: Images of Past and Future Environments; Springer: Berlin/Heidelberg, Germany, 2006.

4. Downes, G.; Drew, D.M. Climate and growth influences on wood formation and utilisation. South. For. 2008, 70, 155-167. [CrossRef]

5. Zobel, B.J.; van Buijtenen, J.P. Wood Variation: Its Causes and Control; Springer: Berlin, Germany, 1989.

6. Camarero, J.J.; Rozas, V.; Olano, J.M. Minimum wood density of Juniperus thurifera is a robust proxy of spring water availability in a continental Mediterranean climate. J. Biogeogr. 2014, 41, 1105-1114. [CrossRef]

7. Zeller, L.; Ammer, C.; Annighöfer, P.; Biber, P.; Marshall, J.; Schütze, G.; del Río, M.; Pretzsch, H. Tree ring wood density of Scots pine and European beech lower in mixed-species stands compared with monocultures. For. Ecol. Manag. 2017, 400, 363-374. [CrossRef]

8. Auty, D.; Achim, A.; Macdonald, E.; Cameron, A.D.; Gardiner, B.A. Models for predicting wood density variation in Scots pine. Forestry 2014, 87, 449-458. [CrossRef]

9. Piutti, E.; Cescatti, A. A quantitative analysis of the interactions between climatic response and intraspecific competition in European beech. Can. J. For. Res. 1997, 27, 277-284. [CrossRef]

10. Carson, S.D.; Cown, D.J.; McKinley, R.B.; Moore, J.R. Effects of site, silviculture and seedlot on wood density and estimated wood stiffness in radiate pine at mid-rotation. N. Z. J. For. Sci. 2014, 44, 26. [CrossRef]

11. Bontemps, J.D.; Gelhaye, P.; Nepveu, G.; Hervé, J.C. When tree rings behave like foam: moderate historical decrease in the mean ring density of common beech paralleling a strong historical growth increase. Ann. For. Sci. 2013, 70, 329-343. [CrossRef]

12. Jozsa, L.A.; Middleton, G.R. A Discussion of Wood Quality Attributes and Their Practical Implications; Special Publication No. SP-34; Canada-British Columbia Partnership Agreement on Forest Resource Development: FRDA II.; Forintek Canada Corporation: Vancouver, BC, Canada, 1994.

13. Mansfield, S.D.; Parish, R.; Goudie, J.; Kang, K.Y.; Ott, P. The effects of crown ratio on the transition from juvenile to mature wood production in lodge pole pine in western Canada. Can. J. For. Sci. 2007, 37, 1450-1459. 
14. Linares, J.C.; Delgado-Huertas, A.; Carreira, J.A. Climatic trends and different drought adaptive capacity and vulnerability in a mixed Abies pinsapo-Pinus halepensis forest. Clim. Chang. 2011, 105, 67-90. [CrossRef]

15. Sánchez-Salguero, R.; Camarero, J.J.; Dobbertin, M.; Fernández-Cancio, A.; Vilà-Cabrera, A.; Manzanedo, R.D.; Navarro-Cerrillo, R.M. Contrasting vulnerability and resilience to drought-induced decline of densely planted vs. natural rear-edge Pinus nigra forests. For. Ecol. Manag. 2013, 310, 956-967. [CrossRef]

16. Sohn, J.A.; Saha, S.; Bauhus, J. Potential of forest thinning to mitigate drought stress: A meta-analysis. For. Ecol. Manag. 2016, 380, 261-273. [CrossRef]

17. Linares, J.C.; Camarero, J.J.; Carreira, J.A. Interacting effects of changes in climate and forest cover on mortality and growth of the southernmost European fir forests. Glob. Ecol. Biogeogr. 2009, 18, 485-497. [CrossRef]

18. Sánchez-Miranda, A.; Jiménez, M.N.; Gálvez Garrido, C.R.; Navarro, F.B.; Ripoll, M.A.; Hevia, A.; Sánchez-Salguero, R. Thinning Modulates Climate-Growth Responses of Pinus Halepensis Mill. under Semiarid Mediterranean Conditions; Hevia, A., Sánchez-Salguero, R., Linares, J.C., Olano, J.M., Camarero, J.J., Gutiérrez, E., Helle, G., Gärtner, H., Eds.; TRACE-Tree Rings in Archaeology, Climatology and Ecology; Scientific Technical Report 16/04; GFZ German Research Centre for Geosciences: Potsdam, Germany, 2016; Volume 14, pp. 111-119.

19. Peltola, H.; Kilpeläinen, A.; Sauvala, K.; Räisänen, T.; Ikonen, V.P. Effects of early thinning regime and tree status on the radial growth and wood density of Scots pine. Silva Fenn. 2007, 41, 489-505. [CrossRef]

20. Blanco, J.A.; Zavala, M.A.; Imbert, J.B.; Castillo, F.J. Sustainability of forest management practices: Evaluation through a simulation model of nutrient cycling. For. Ecol. Manag. 2005, 213, 209-228. [CrossRef]

21. Tang, J.; Qi, Y.; Xu, M.; Misson, L.; Goldstein, A.H. Forest thinning and soil respiration in a ponderosa pine plantation in the Sierra Nevada. Tree Physiol. 2005, 25, 57-66. [CrossRef] [PubMed]

22. Ericson, B. Effect of Thinning on the Basic Density and Content of Latewood and Heartwood in Scots Pine and Norway Spruce; Research Notes No. 10, Department of Forest Yield Research; Royal College of Forestry: Stockholm, Sweden, 1966.

23. Lin, F.C.; Chung, C.H.; Zeng, J.L.; Yang, T.H.; Wang, S.Y.; Lin, C.J. Effect of thinning on the ring characteristics of Japanese cedar plantation trees. J. Wood Sci. 2012, 58, 104-112. [CrossRef]

24. Filipescu, C.N.; Lowell, E.C.; Koppenaal, R.; Mitchell, A.K. Modeling regional and climatic variation of wood density and ring width in intensively managed Douglas-fir. Can. J. For. Res. 2014, 44, 220-229. [CrossRef]

25. Kellomäki, S.; Koski, V.; Niemelä, P. Management of forest ecosystems. In Forest Resources and Sustainable Management; Kellomäki, S., Ed.; Gummerus Oy: Jyväskylä, Finland, 1998; pp. 219-309.

26. Gardiner, B.A.; Leban, J.M.; Auty, D.; Simpson, H.L. Models for predicting the wood density of British-grown Sitka spruce. Forestry 2011, 84, 119-132. [CrossRef]

27. Peltola, H.; Gort, J.; Pulkkinen, P.; Zubizarreta Gerendiain, A.; Karppinen, J.; Ikonen, V.P. Differences in growth and wood density traits in Scots pine (Pinus sylvestris L.) genetic entries grown at different spacing and sites. Silva Fenn. 2009, 43, 339-354. [CrossRef]

28. Fajardo, A. Wood density is a poor predictor of competitive ability among individuals of the same species. For. Ecol. Manag. 2016, 372, 217-225. [CrossRef]

29. Mörling, T. Evaluation of annual ring width and ring density development following fertilization and thinning of Scots pine. Ann. For. Sci. 2002, 59, 29-40. [CrossRef]

30. Schneider, R.; Zhang, S.Y.; Swift, D.E.; Bégin, J.; Lussier, J.M. Predicting selected wood properties of jack pine following commercial thinning. Can. J. For. Res. 2008, 38, 2030-2043. [CrossRef]

31. Jaakkola, T.; Mäkinen, H.; Saranpää, P. Wood density in Norway spruce: Changes with thinning intensity and tree age. Can. J. For. Res. 2005, 35, 1767-1778. [CrossRef]

32. Megraw, R.A. Wood Quality Factors in Loblolly Pine. The Influence of Tree Age, Position in Tree, and Cultural Practice on Wood Specific Gravity, Fiber Length, and Fibril Angle; TAPPI Press: Atlanta, GE, USA, 1985.

33. Paul, B.H. Specific gravity changes in southern pines after release. South. Lumberman 1958, 163, $122-124$.

34. Larson, P.R. Wood Formation and the Concept of Wood Quality; Bulletin No. 7; Yale University School of Forestry: New Haven, CT, USA, 1969.

35. Primicia, I.; Camarero, J.J.; Imbert, J.B.; Castillo, F.J. Effects of thinning and canopy type on growth dynamics of Pinus sylvestris: Inter-annual variations and intra-annual interactions with microclimate. Eur. J. For. Res. 2013, 132, 121-135. [CrossRef]

36. Peltola, H.; Miina, J.; Rouvinen, I.; Kellomäki, S. Effect of early thinning on the diameter growth distribution along the stem of Scots pine. Silva Fenn. 2002, 36, 813-825. [CrossRef] 
37. Splechtna, B.E.; Dobry, J.; Klinka, K. Tree-ring characteristics of subalpine fir (Abies lasiocarpa (Hook.) Nutt.) in relation to elevation and climatic fluctuations. Ann. For. Sci. 2001, 57, 89-100. [CrossRef]

38. Koubaa, A.; Zhang, S.Y.T.; Makni, S. Defining the transition from earlywood to latewood in black spruce based on intra-ring wood density profiles from X-ray densitometry. Ann. For. Sci. 2002, 59, 511-518. [CrossRef]

39. Papadakis, J. Climates of the World, Their Classification, Similitudes, Differences, and Geographic Distribution; Self-Edited: Buenos Aires, Argentina, 1970.

40. Walter, H. Climatic diagrams as a means to comprehend the various climatic types for ecological and agriculture purposes. In The Water Relation of Plants, Proceedings of the Symposium of the British Ecological Society, London, UK, 28-30 March 1963; Rutter, A.J., Whitehead, F.H., Eds.; Blackwell Scientific Publications: London, UK, 1963; pp. 3-9.

41. Running, S.W.; Nemani, R.R.; Hungerford, R.D. Extrapolation of synoptic meteorological data in mountainous terrain and its use for simulating forest evapotranspiration and photosynthesis. Can. J. For. Res. 1987, 17, 472-483. [CrossRef]

42. Lo, Y.H.; Blanco, J.A.; Seely, B.; Welham, C.; Kimmins, J.P. Generating reliable meteorological data in mountainous areas with scarce presence of weather records: The performance of MTCLIM in interior British Columbia, Canada. Environ. Modell. Softw. 2011, 26, 644-657. [CrossRef]

43. González de Andrés, E.; Seely, B.; Blanco, J.A.; Imbert, J.B.; Lo, Y.H.; Castillo, F.J. Increased complementarity in water-limited environments in Scots pine and European beech mixtures under climate change. Ecohydrology 2016. [CrossRef]

44. Andrew, L. Simple Experimental Design for Forestry Trials; FRI Bulletin No. 71; Forest Research Institute: Rotorua, New Zealand, 1986.

45. QMS. Tree Ring Analyzer Users Guide Model QTRS-01X; Quintek Measurement Systems: Knoxville, TN, USA, 1999.

46. Polge, H. Fifteen years of wood radiation densitometry. Wood Sci. Technol. 1978, 12, 187-196. [CrossRef]

47. Mäkinen, H.; Hynynen, J. Wood density and tracheid properties of Scots pine: Responses to repeated fertilization and timing of the first commercial thinning. Forestry 2014, 87, 437-447. [CrossRef]

48. Holmes, R.L. Computer-assisted quality control in tree-ring dating and measuring. Tree-Ring Bull. 1983, 43, 69-78.

49. Vicente-Serrano, S.M.; Beguería, S.; López-Moreno, J.I. A Multi-scalar drought index sensitive to global warming: The Standardized Precipitation Evapotranspiration Index-SPEI. J. Clim. 2010, 23, 1696-1718. [CrossRef]

50. Gutiérrez, E. Dendroclimatological study of Pinus sylvestris L. in southern Catalonia (Spain). Tree-Ring Bull. 1989, 49, 1-9.

51. Bogino, S.; Fernández Nieto, M.J.; Bravo, F. Climate effect on radial growth of Pinus sylvestris at its southern and western distribution limits. Silva Fenn. 2009, 43, 609-623. [CrossRef]

52. Del Río, M.; Bravo-Oviedo, A.; Pretzsch, H.; Löf, M.; Ruíz-Peinado, R. A review of thinning effects on Scots pine stands: From growth and yield to new challenges under global change. For. Syst. 2017, 26, eR03S. [CrossRef]

53. Blanco, J.A.; Imbert, J.B.; Castillo, F.J. Thinning affects nutrient resorption and nutrient-use efficiency in two Pinus sylvestris stands in the Pyrenees. Ecol. Appl. 2009, 19, 682-698. [CrossRef] [PubMed]

54. Blanco, J.A.; Imbert, J.B.; Castillo, F.J. Thinning affects Pinus sylvestris needle decomposition rates and chemistry differently depending on site conditions. Biogeochemistry 2011, 106, 397-414. [CrossRef]

55. Guller, B. The effects of thinning treatments on density, MOE, MOR and maximum crushing strength of Pinus brutia Ten. wood. Ann. For. Sci. 2007, 64, 467-475. [CrossRef]

56. Tasissa, G.; Burkhart, H.E. Modeling thinning effects on ring width distribution in loblolly pine (Pinus taeda). Can. J. For. Res. 1997, 27, 1291-1301. [CrossRef]

57. Moschler, W.W.; Dougal, E.F.; McRae, D.D. Density and growth ring characteristics of Pinus taeda L. following thinning. Wood Fiber Sci. 1989, 21, 313-319.

58. Pape, R. Influence of thinning and tree diameter class on the development of basic density and annual ring width in Picea abies. Scand. J. For. Res. 1999, 14, 27-37. [CrossRef]

59. Pukkala, T.; Miina, J.; Kellomäki, S. Response to different thinning intensities in young Pinus sylvestris. Scand. J. For. Res. 1998, 13, 141-150. [CrossRef] 
60. Sohn, J.A.; Hatig, F.; Kohler, M.; Huss, J.; Bauhus, J. Heavy and frequent thinning promotes drought adaptation in Pinus sylvestris forests. Ecol. Appl. 2016, 26, 2190-2205. [CrossRef] [PubMed]

61. Koga, S.; Zhang, S.Y.; Bégin, J. Effects of precommercial thinning on annual radial growth and wood density in balsam fir (Abies balsamea). Wood Fiber Sci. 2002, 34, 625-642.

62. Jones, P.D.; Fox, T.R. Wood density in Pinus taeda $x$ Pinus rigida and response 10 years after thinning in Virginia. For. Prod. J. 2007, 57, 70-73.

63. MacPeak, M.D.; Burkart, L.F.; Weldon, D. Comparison of grade, yield, and mechanical properties of lumber produced from young fast-grown and older slow-grown planted Slash pine. For. Prod. J. 1990, 40, 11-14.

64. Wodzicki, T.J. Natural factors affecting wood structure. Wood Sci. Technol. 2001, 3, 5-26. [CrossRef]

65. Rozenberg, P.; Van Loo, J.; Hannrup, B.; Grabner, M. Clonal variation of wood density record of cambium reaction to water deficit in Picea abies (L.) Karst. Ann. For. Sci. 2002, 59, 533-540. [CrossRef]

66. Bréda, N.; Huc, R.; Granier, A.; Dreyer, E. Temperate forest trees and stands under severe drought: A review of ecophysiological responses, adaptation processes and long-term consequences. Ann. For. Sci. 2006, 63, 625-644. [CrossRef]

67. Martínez-Vilalta, J.; Piñol, J. Drought-induced mortality and hydraulic architecture in pine populations of the NE Iberian Peninsula. For. Ecol. Manag. 2002, 161, 247-256. [CrossRef]

68. Sánchez-Salguero, R.; Navarro-Cerillo, R.M.; Camarero, J.J.; Fernández-Cancio, A. Selective drought-induced decline of pine species in southeastern Spain. Clim. Chang. 2012, 113, 767-785. [CrossRef]

69. Chuine, I.; Yiou, P.; Viovy, N.; Seguin, B.; Daux, V.; Le Roy Ladurie, E. Historical phenology: grape ripening as a past climate indicator. Nature 2004, 432, 289-290. [CrossRef] [PubMed]

70. Camarero, J.J.; Gazol, A.; Sangüesa-Barreda, G.; Oliva, J.; Vicente-Serrano, S.M. To die or not to die: early-warning signals of dieback in response to a severe drought. J. Ecol. 2015, 103, 44-57. [CrossRef]

71. González de Andrés, E.; Camarero, J.J.; Blanco, J.A.; Imbert, J.B.; Lo, Y.H.; Sangüesa-Barreda, G.; Castillo, F.J. Tree-to-tree competition in mixed European beech-Scots pine forests has different impacts on growth and water-use efficiency depending on site conditions. J. Ecol. 2017. [CrossRef]

72. Eilmann, B.; Zweifel, R.; Buchmann, N.; Pannatier, E.G.; Rigling, A. Drought alters timing, quantity, and quality of wood formation in Scots pine. J. Exp. Bot. 2011, 62, 2763-2771. [CrossRef] [PubMed]

73. Zweifel, R.; Item, H.; Häsler, R. Link between diurnal stem radius changes and tree water relations. Tree Physiol. 2001, 21, 869-877. [CrossRef] [PubMed]

74. IPCC. Fourth Assessment Report of the Intergovernmental Panel on Climate Change; Cambridge University Press: Cambridge, UK; New York, NY, USA, 2007.

75. Sánchez-Salguero, R.; Camarero, J.J.; Gutiérrez, E.; González Rouco, F.; Gazol, A.; Sangüesa-Barreda, G.; Andreu-Hayles, L.; Linares, J.C.; Seftigen, K. Assessing forest vulnerability to climate warming using a process-based model of tree growth: Bad prospects for rear-edges. Glob. Chang. Biol. 2016. [CrossRef] [PubMed]

76. Taylor, F.W.; Burton, J.D. Growth ring characteristics, specific gravity, and fiber length of rapidly grown loblolly pine. Wood Fiber 1982, 14, 204-210.

77. Kärenlampi, P.P.; Riekkinen, M. Maturity and growth rate effects on Scots pine basic density. Wood Sci. Technol. 2004, 38, 465-473. [CrossRef]

(C) 2018 by the authors. Licensee MDPI, Basel, Switzerland. This article is an open access article distributed under the terms and conditions of the Creative Commons Attribution (CC BY) license (http://creativecommons.org/licenses/by/4.0/). 